\title{
THE CORRELATION BETWEEN RELIGIOUS IDENTITY AND NATIONAL IDENTITY - THE PARTICIPANTS OF STUDENT PROTEST IN BELGRADE 1996/97
}

\author{
Saša NEDELJKOVIĆ \\ Department of Ethnology and Anthropology, University of Belgrade \\ Cika Ljubina 18-20, 11000 Belgrade, Yugoslavia
}

\begin{abstract}
The aim of this research is to find out in what degree religious identity in Serbian society has become a self-governed identity, a kind of an identity for itself, or, in what degree it is still part of national identity. Is the religious belonging (religious identity) a reliable mark of ethnicity and, if so, in what measure? The research has been done on the participants of student protest (SP) in Belgrade in winter 1996/97. The relationship between religious belonging (religious identity) and national identity is observed in relation to universal processes of cosmopolitization, individualization and retraditionalization.

Keywords: national identity, religious identity, student protest, individualization, tradition
\end{abstract}

There is a religious aspect concerning the distinction between the terms "individuality" (inseparable element of society) and "personality" (self-conscious and free creative subject). Paraphrasing BERDJAJEV, we can say that ethnic religion originates in the community of individuals, and universal religion of Christian type in the community of personalities. ${ }^{1}$ The concept of universal religion can be considered, according to Jung, as a more developed form than the concept of ethnic religions. ${ }^{2}$ One of the interesting, but empirically inadequately explored issues, is identifying, if possible, the reflection in religion of some problems such as forming and development of the individuality into personality; the relation of the individual to collective and ethnic culture and tradition, differences in relation among mentioned problems between (conditionally speaking) individualities and personalities and disintegration within ethnic community. ${ }^{3}$

The ideal model of ethnic group implies acceptance of the same religious form ethnic religion by all the members of a certain ethnic group; social and ethnic community coincide with religious community; meaning that religious identity is a part of ethnic identity. In many areas in the past, ethnic identity implied certain religious

${ }^{1}$ See N. BerdJAJEV, "Ljudska licnost i marksizam" ("Human Personality and Marxism"), in "Komunizam i krscani" (Communism and Christians), Zagreb, 1937, 164-187; also see in New Testament, "The Epistle to Colossians III" (9-11); also see K. G. JUNG, Psihologija i alhemija (Psychology and Alchemy), Zagreb, 1984, 42-43; also in BAHTIJAREVIC, Religijsko pripadanje u uvjetima sekularizacije drustva (Religious Belonging in the Conditions of Secularity of Society), Zagreb, 1975, 13.

2 See K. G. Jung, Psiholoske rasprave (Psychological Debates), Novi Sad, 1977, 132.

${ }^{3}$ See Z. BAUMAN, "From Pilgrim to Tourist - or a Short History of Identity", in Questions of Cultural Identity, ed. S. HALL and P. DU GAY, London, 1997, 18-36. 
belonging. Disintegration of ethnic identity existed, but it was within ethno-religious ideology. Within nations with strong ethnic features, so called 'belated nations', such as Serbia, religious disintegration and religious pluralism are weaker and they have narrower paths than within more developed nations. That is why the problem of connection between ethnic and religious belonging among the Serbs today is very interesting but fairly unexplored. I wanted to establish the connection between religious identity and the degree of achieved individuality, in fact the degree of achieved self-identity.

To achieve the goal set, we need to classify the various relations toward religion (to establish the existence of various layers within religious identity of Serbs), to measure the ethnicity of those layers, and then compare the results.

I searched for the interviewees among the members of the Student Protest 1996/97 in Belgrade for several reasons. ${ }^{4}$ They showed with their effort to influence social, political and national problems that they have a certain shape of national identity. Recent research of this population shows that it is very open to new ideas, ${ }^{5}$ and it is logical to presume that the sample studied is more exposed in comparison to the average population. I presumed that this population could give more complete replies than other populations, because of its educational level and of being well informed. By studying orientations and attitudes of the youth, the future development of society can be foreseen in a certain way. This population is interesting because their age is often a period when durable attitudes towards religion are formed. ${ }^{6}$

The research was done in special surroundings, in many ways. The Serbs in the past were monoconfessional, and a certain form of religion (Orthodox Christianity), represented the core of their ethnic consciousness and their ethnic identity; ${ }^{7}$ any change of the religion was often followed by the change of nationality, ${ }^{8}$ after some time. "Orthodox Serb", has become a concept not only referring to national and confessional belonging, but also to religious purity and originality. The complex "chosen nation" has become deeply rooted in the Serbian collective psyche.

Historical circumstances (five centuries of Turkish occupation) stopped the development of Christian consciousness, which was evident in medieval Serbia. Bio-

${ }^{4}$ Student Protest was a protest against irregularity in local elections in Serbia.

${ }^{5}$ See B. KUZMANOVIC, Setnjom u slobodu - vrednosne orijentacije i politicki stavovi ucesnika Studentskog protesta 96/97, u Ajmo, ajde, svi u setnju - gradjanski i studentski protest 96/97 (Walking into Freedom - Value Orientations and Political Attitudes of the Members of Students' Protest 96/97, in Let's all of us go for a walk - civilian and student protest 96/97), Belgrade, 1997, 58-59.

${ }^{6}$ V. JEROTIC, Hriscanstvo i psiholoski problemi coveka (Christianity and Psychological Problems of Man), Belgrade, 1997, 103.

${ }^{7}$ Foreign observers noticed a long time ago that the Serbian Orthodox Church is "the essential expression of Serb nationalism", and "The Serb Church exercised a nationalistic rather than a religious leadership". M. RISTOVIC, "Socijalna struktura Jugoslavije - jedna analiza britanskog Foreign Office Research Department-a s kraja 1944, godine" (Social Structure of Yugoslavia - a research done by British Foreign Office Research Department, end of 1944), in Annual of Social History, Year 2, Book 1, Belgrade, 1995, 104-117, 115.

${ }^{8}$ See J. CVIJIC, Balkansko poluostrvo (The Balkan Peninsula), Belgrade, 1987, 176. 
logical survival and nourishing cultural identity were the reasons why the Christian Church was integrated into national culture and became the extreme intercessor of national interests. That was the condition, which caused the institution of the Church to be profane, resulting in the nationalisation of Christian symbols and revitalisation of pagan religion. A ritual type of worshippers was developed in Serbia as the dominant type. That is the type of worshipping with a modest knowledge of religious studies, and showing the state of being religious by the practice of religious customs established by tradition. Religion was not closely connected with sacral institutions. The cult of ancestors ${ }^{9}$ had an important place in religious life of the type.

The formal discarding of communist pseudo Christian ideology at the end of the eighties, was logically followed by an emotionally charged return to traditional ethnic religion, wrapped in Christian symbols, and a new return to tradition. But not all the members of the nation participated in this; in fact not all of them accepted it with the same intensity. Disintegration of religious identity became evident, because of enlarged individuality, because of different beliefs in religious function, and because of the difference in the achieved degree of development of religious consciousness, and consciousness itself. Serbian ethnos became disintegrated not only in a religious, but also, in a general cultural way. The basic moments in the history of religion of the Serbs can be summed up as: slow forming of old Slav religion, acceptance of the Eastern version of Christianity in the Middle Ages, religious reaction in the form of the Bogomil movement in the twelfth and the thirteenth centuries, many centuries of exposure to Islam and Catholicism and becoming a part of them and finally the acceptance of communism as a pseudo religious ideology in the second half of the twentieth century.

The particularity of the group studied means that unsolved ethnic and national problems have been existing ever since, and that confessional belonging is often the key element of national belonging.

Results of recent research show that there was a dominant process of secularisation $^{10}$ concerning the student population in the period between 1945 and 1980. Since 1980, or several years before, there has been an increased number of worshippers (believers) and a decline in the number of atheists; that means that the process of theisation ${ }^{11}$ has begun. In the group of students questioned, there are $12 \%$ more

${ }^{9}$ See PAVICEVIC, Sociologija religije sa elementima filozofije religije (Sociology of Religion with the Elements of Philosophy of Religion), Belgrade, 1980, 188 ff.; and V. CAJKANOVIC, O magiji i religiji, (About Magic and Religion), Belgrade, 1985, 264.

${ }^{10}$ According to many researches, Belgrade is the most secular area in Serbia. See D. B. DJORDJEVIC, Studenti i religija (Students and Religion), Nis, 1987, 29.

${ }^{11}$ There are data for the student population in Split, in Croatia for the period 1969-1980; I believe that the process is much the same, it may be said that it was even stronger in Serbia. More data about the research in Split can be found in S. VRCAN, Studenti i religija, izmedju cvrste povezanosti za religiju i masovnog otudjivanja od religije (vezanost studenata Sveucilista u Splitu za religiju) (Students and Religion: between a sort of relation to religion and massive alienation from it (relation of students from the Split University to religion), Sociology 1-2, Belgrade, 1981. Since 1980, the number of worshippers in Serbia has doubled, and the number of atheists has halved. Thorough data can be found in D. B. DJORDJEVIC, op. cit. 
interviewees who are now more religious than those who are less religious in comparison to the previous part of their life.

The student population within the Serbian society is specific because it was formally more non-religiously and secularly established in comparison to the average population. Apart from being different from the average for the Serbian nation, it is different according to its religious identity from populations of the same kind in different areas: it was, in comparison to the same population in Split in the eighties, non-religious and/or atheist. ${ }^{12}$

Samples were 218 students attending almost all Belgrade faculties and several colleges, including the Theological Faculty of the Serbian Orthodox Church. The ratio of women and men was 51\%: 49\%; according to permanent addresses, the interviewees are from all parts of FRY (almost two thirds from Belgrade), and several from the Republic Srpska (in Bosnia); 95\% are Serbian and 5\% Montenegrin nationality, by objective ethnic criterion. Interviewees were chosen at random. The number of interviewed students, according to some estimations, represents about $0.5 \%$ of all the participants of student protest. To give better access into the matter, two smaller groups were interviewed afterwards, using a modified questionnaire: one group had 66, and the other 78 students from different faculties. The sample was not representative for the whole student population: the conclusion according to research upon this sample leads to tendencies and orientations. ${ }^{13}$

Interviewees see and search for an aim, comfort and help for life orientation in religion. They also see salvation, meaning, and the possibility to direct and control energy, a connection with the past. Religion means for them the possibility of observing only one aspect of reality. They believe that the Church is not the same as before or what it should be. According to many of them, the Serbian Orthodox Church changed into a solely national institution, replacing religious activity, and the clergy is morally corrupted. That is why a great number of interviewees, although religious, are against the church, church organization and the clergy: they believe that mediators between God and man are not needed any more, and they try to build their personal relation with God free from any models. Many interviewees tend to build their relation with God, which is based on rational beliefs and scientific facts, and which is not based on strict obedience and mystical getting accustomed. The term "God" is connected with the sphere of noumenal, and his actions in the phenomenal world are not distinctly defined. Individuals make a distinction between individual

\footnotetext{
${ }^{12}$ Comparing results of research on worshipping among the students in Split (Croatia) in 1980 and results from Nis (Serbia) 1985, we come to the conclusion that the students in Nis were far less religious, in fact that they were more atheists ( $80 \%$ stated that they were non-religious, i.e. atheists). Research in Nis in 1985 shows that students were more non-religious than the rest of the population in that part of Serbia. See S. VRCAN, op. cit., 4 ff; also see D. B. DJORDJEVIC, op. cit., 29 and 62.

${ }^{13}$ See about the methodology of examining religious identity in S. BAHTIJAREVIC op. cit., Zagreb, 1975; D. B. DJORDJEVIC, op. cit., V. VRATUŠA-ZUNJIC, Odnos verske pripadnosti, religiozne samoidentifikacije i medjuetnicke distance u bivsoj Jugoslaviji krajem osamdesetih, rezime priloga za IV godisnju konferenciju JUNIR-a (Relation of religious belonging, religious self-identification and inter-ethnic distances in former Yugoslavia at the end of the eighties, summary of the text for the Fourth Conference of JUNIR), Niska Banja, 1997.
} 
and collective religion; according to them, individual religion is for contemplative people and the collective one is for the masses. A number of students pray to God when it suits them or when they are in danger, and forget that when everything is all right. Traditional worshippers often make no distinction between these terms: "religion" and "the Church", "Serbian" and "Orthodox", "tradition" and "religious custom". On the other hand, not many of them make a distinction between "atheism" and "agnosticism". Atheism is often understood as a common term, which includes all non-Church forms of religion. Superstition and fortune telling are considered to be the lowest level of religious consciousness and Christianity the highest; according to them, it is not sufficient to belong to Christianity formally, and in that way to be called a Christian. Some of the students see a cultural barrier in Orthodox Christianity which stands in the way of globalism; for them, Orthodox Christianity is the most human, liberal and the most spiritual form of Christianity. Belief that people from the West are spiritually inferior in comparison to the people from the East (the Serbs are included) is far from being uncommon. Others consider Orthodox Christianity as an unsuccessful attempt at keeping the values of early Christianity, in fact a cover for nationalism. Most of the interviewees take part in these traditional rituals. Some of them try in that way to build and keep their own identity, and others consider rituals to be empty forms which are practiced to avoid attracting attention and not to provoke negative reactions from their surroundings. Students are conscious that the old Slav pantheon lives in Orthodox religion. Although, a number of them do not know whether they worship (believe) or not, there is a negligible number who are aloof and who are against religion.

According to some answers it is possible to distinguish several groups of interviewees. First of all, there is a group of interviewees who fully accept the model of religion offered by the Serbian Orthodox Church - we can call them "Church" or "Convinced" Orthodox worshippers or believers (they represent one seventh $-14 \%$ of the total number of interviewees). Second, there is a group which accepts eroded or modified forms of Orthodox Christian religion; their relation to the Church is weaker, and often this form is called "folk Orthodox religion" (almost half of the interviewees - 44\%). ${ }^{14}$ Both church and non-church Serbian Orthodox Christians accept the mixture of Christian and pagan religion, but church ones use more Christian symbols, whereas non-church ones use pagan symbols. As the third group, we have atheists, in fact non-worshippers (22\%). The fourth group are worshippers, but their form of being religious is formed in harmony with other models: we can call

\footnotetext{
${ }^{14}$ It is possible to distinguish four degrees of Church distinction, i.e. religious participation; total acceptance of Church model (14\% of interviewees), partial acceptance (12\%), acceptance of customs without going to church $(15 \%)$ and very informal and undefined identification with Church conviction $(18 \%)$. I formed CWO group from the first group, and WMO group from the other three. For more detail on "folk Orthodox religion" see D. BANDIC, Carstvo zemaljsko i carstvo nebesko, ogled o narodnoj religiji (The Empire of Earth and the Empire of Heaven, experiments about folk religion), second, enlarged edition, Belgrade, 1997, 239 ff., and D. BANDIC, Narodna religija Srba u 100 pojmova (Serbian Folk religion in 100 notions), Belgrade, 1991.
} 
them followers of alternative forms of religion (19\%) ${ }^{15}$ It is characteristic for all the unconvinced worshippers of Orthodox religion that, they all, in a certain way accept the traditional, Orthodox model of religious life; all the alternative ones are characterized by a non-traditional type of religion.

Most of them accept a modified form of Orthodox religion, and the smallest group are convinced worshippers of the Serbian Orthodox Church. Not many of them are actually connected to Orthodox religion, and there are many of them who are traditionally connected to Orthodox religion, without personal religiosity, and with a clear consciousness about confessional background. There are many of them as well, who accept the confessional background despite the lack of rational sense and being non-religious; they consider the traditional model as a part of their cultural heritage. It is shown in one of the groups interviewed afterwards that full identification with Orthodox Christianity exists only in one fifth of the cases, and full and/or partial in $45 \%$ of the interviewees; formal acceptance of traditional religion exists in $83 \%$ of interviewees (they declare themselves in certain situations as Orthodox). Full religious identification and religious participation can be found in $14 \%$, and this is the very same percentage of those who would change their religion for a more pleasant life. Clearly defined Orthodox religious identification exists if full Orthodox religious participation is present. Within the group where religious participation is not full, religious identification is heterogeneous and inconsistent. A check with the control group shows that agnostics often declared themselves as atheists, and ritual life atheists and agnostics are often like the life of Orthodox worshippers.

Research on ethnicity demands research on inner and outer aspects of ethnical being (inner homogeneity of the group and the distance towards others). That is why I studied ethnicity in different ways: according to national declaration, scale of national ties, scale of traditionalism, ethnic distance, ethnic stereotypes and auto stereotypes, and with the help of attitudes towards certain social problems. ${ }^{16}$ Apart from ethnicity, some other parameters were also taken into account. One of them is authoritarian.

Interviewees from the groups of convinced Orthodox worshippers and worshippers of modified Orthodox religion are more traditional, national and authoritarian than the interviewees from the groups of atheists and alternative ones. ${ }^{17}$ Differences

\footnotetext{
15 "Alternative" group is formed of non-confessional worshippers (15\% of all interviewees), undecided - undefined (4\%), and members of small religious sects $(1 \%)$.

${ }^{16}$ I took scales for researching social attitudes in shortened and modified form from Z. GoLuBOVIC, B. KuZMANOVIC, M. VASOVIC, Drustveni karakter i drustvene promene u svetlu nacionalnih sukoba (Social Character and Social Changes in the Light of National Conflicts), Belgrade, 1995.

${ }^{17}$ I will show results on the scale of authoritarian, scale of traditionalism and the scale of national ties. All the scales included eight statements, and each of them could be answered with one out of five answers: starting with full agreement with the given statement to full disagreement with it. The maximum score on each of these scales was 40 points (maximum authoritarian, i.e. traditionalism, i.e. national ties), and minimum 8 points; the theoretical middle was 24 points, and that was the result which conditionally represented the border between those who were not authoritarian, not traditional and not nationally
} 
in ethnicity among these groups are sometimes minimal, and sometimes significant (for example in the scale of national ties).$^{18}$ Religious belonging is a true parameter of ethnic identity only on the group level, if individuals are considered, it should be checked. Certain forms of religious belonging are a true parameter of ethnicity only in comparison to another type of religious belonging, but not true in the absolute sense. This means that people who accept the traditional model of religion have stronger ties to their nation than those who do not accept this model; but it does not mean that followers of the traditional model would always show strong ethnicity.

Full acceptance of the Orthodox model of religiosity is in 5 of 6 cases connected to nationalism; in these cases through religion the nation is glorified. On the other hand, nationally oriented persons, in three quarters of the cases do not fully accept the Orthodox model of religiosity. ${ }^{19}$ Almost all of the people who declared themselves to be Orthodox (98.5\%) have articulated national identity (they declared themselves national); on the other hand, almost every eighth (12\%) interviewee who firmly declared being national, did not declare being Orthodox. More than one third of the interviewees (38\%), although formally identified with Orthodox religion, try to fulfil real religious need in some other way. ${ }^{20}$

Interviewees refer to Orthodox religion as one of the basic national institutions and the Serbian Orthodox Church is considered to be one of the basic national organizations. Acceptance of Orthodox religion is not the condition for development of nationalism; in fact Orthodox religion is not the only nucleus of national consciousness; although rare, there are cases when nationalism does not try to find support in religion. Two kinds of nationalism exist: both sacral and profane orientation, and the first one is more numerous. Generally speaking, when the model of being religious is closer to the Church model it is more connected to nationalism, authoritarian and traditionalism. The degree of acceptance of the traditional model of reli-

connected, on the one side, and on the other side there were those who had these characteristics. Average results on the authoritarian scale are: convinced Orthodox Worshippers (CWO) - 18.7 points; worshippers of modified Orthodox Religion (WMO) - 16.93, alternative (ALT) - 16.90; atheists (non-believers) (ATE) - 14.8. On the scale of traditionalism, the following results were obtained: CWO -24.7 points, WMO - 23.2; ATE - 22.7; ALT - 21.7. On the scale of national ties, the results were: CWO - 28.2 points; WMO - 25.3; ATE - 22.3; ALT - 20.7. Ethnic distance was also researched, according to readiness to be married to people of other nationalities. In the CWO group there is aversion in $83.9 \%$ towards at least one nationality in respect of marrying, in the WMO group $81.4 \%$, ALT - 64.3 and in the group ATE $56.2 \%$.

${ }^{18}$ More than one third of the interviewees, among the characters from Serbian history, admire Nikola Tesla (36\%), and less than one fifth $(20 \%)$ admire St. Sava, founder of the Serbian Orthodox Church. Atheists and alternatives give priority to N. Tesla, interviewees from WMO admire Nikola Tesla more, whereas those from the CWO give priority to St. Sava. Orthodox people admire Greek people from ancient times (because of their developed democracy and spirituality) and religious "non-traditionalists" admire contemporary English people (because of the successful symbiosis of traditional and contemporary culture).

$1984 \%$ are those who fully accept the Orthodox model of religion and are nationally oriented, i.e. they achieved a higher score than theoretical on the scale of national ties.

$2083 \%$ of interviewees in the control group declared that they were Orthodox, and only $45 \%$ of them accept what their religion preaches. 
gion is conversely proportional to the degree of individual emancipation, i.e. the degree of achieved critical attitude towards authorities and tradition and the degree of constructed personal attitude towards reality and independence.

The spectrum of religious identities of interviewees ranges from those who accept the old-fashioned mystic view of the world stressing the cult of ancestors to those who are super-confessional, universally religious. Atheistic orientation is a consequence of the need to purify consciousness from everything that is needless, ideological, imposed and manipulated through centuries; i.e. an attempt at a new religious identification. ${ }^{21}$ Greater empathy with elements of universal, more than elements of folk religion, shown by a great number of interviewees, is connected with rejection of the national pattern of culture as a mediator between an individual and universal values.

We can observe several layers within the group of Orthodox worshippers, and the description must depend on generalisation and simplification; these layers interweave and they form different variations. The first layer mostly demands from the church affirmation for doing its pagan, i.e. practically magical praxis: in most cases it does not possess an ideologically developed national consciousness. It does not think about religion, and its religious being is described in stock phrases. The individuality of these people is often of the archaic and egoistical type. The second, partially Christian layer includes people who try with the help of the Church to reconcile Christianity and nationalism; they aspire to transcendentalism, belonging to the nation as a higher entity, and they consider globalism as something, which endangers them. They consciously put their individuality into the service of national ideology. As recent events have shown, they have hard times experiencing the crisis of national values; they tend to identify their own destiny with national destiny. The third layer includes different individually contemplative attempts at transcendentalism. The fourth layer formally accepts the Orthodox model because of the lack of courage to reject it, and personally does not identify with it at all (or only a little).

According to conventional criteria, interviewees are educated, young people, but most of them have an attitude to religion similar to the masses; this attitude is not that of a cultural elite. Despite developed intellectuality (precisely, the ability to use terms for practical purposes), many of them do not show FROMM's understanding of the ability to apprehend, regarding exploring the essence. ${ }^{22}$ All of that is reflected in the attitude towards the problem explored, which is often weakly articulated and defined, used term apparatus is often of a modest scope and full of clichés; ready models are accepted without any further elaboration. Although this problem is universal, in the given surroundings it is very indicative..$^{23}$

${ }^{21}$ See V. JEROTIC, op. cit.

22 See the chapter about sense, conscience and religion in FrOMM's book Zdravo drustvo (Healthy Society).

${ }^{23} \mathrm{~S}$. JOVANOVIC claims that wisdom and liveliness of Serbian folk sagacity is not deep, analytical wisdom, but it leads to momentary and unilateral conclusions; see S. JOVANOVIC, "Srpski nacionalni karakter, O kulturnom obrascu" u Karakterologija Srba ("Serbian national character", About the cultural pattern, in Characters of the Serbs), ed. B. JovANOVIC, Belgrade, 1992, 229-242. 
The traditional form of religion presents a less religious institution for the interviewees, and more help in defining general cultural identity - in several cases the construction "Orthodox atheist" 24 was used. There is graduation concerning closeness of the ideal model of the "Serb": several interviewees asked about national belonging replied that they were "Orthodox Serbs", considering it to be the top of the national hierarchy. Personal identity of individualised and non-traditional interviewees chose the World for their reference group, but not nation: religion and nationality are not inseparable categories for them. Their nationalism is evident, for example, during international sports events, and it starts as soon as it hinders personal development (even to a small extent). The long period in which the traditional form of religion was deliberately repressed, left consequences. Many interviewees are not familiar with traditional confession. Traditional confession still has certain secrets for them and a mystical attraction, which is connected with the creation of idealised images. They consider "Orthodox religion" and "Serbian nation" as archetypes of universal values, and not actual reality. Only after getting to know and demystification of traditional confession, could these interviewees form a lasting vision of religion.

Non-traditional religious interviewees are against tradition which obligates and restrains, and they are for tradition which enlightens and gives orientation. It is probably going to become clearer when re-traditional impulse weakens. Efforts made by certain structures aiming at making cannons of satisfying religious needs, represent attempts of those structures to achieve survival, and they are against the tendency of achieving positive freedom. They are against the need of the individual to accede the reality spontaneously and according to personal needs. As Mihail NAJMI quoted in the book Mirdad: "Which ancestors can claim the man whose only ancestor is God?"

BAHTIJAREVIC, Stefica

\section{LITERATURE}

1975: Religijsko pripadanje u uvjetima sekularizacije drustva, Zagreb.

BANDIC, Dusan

1991: Narodna religija Srba u 100 pojmova, Beograd.

1997: Carstvo zemaljsko i carstvo nebesko, Ogledi o narodnoj religiji, drugo, dopunjeno izdanje, Beograd.

BAUMAN, Zigmunt

1997: From Pilgrim to Tourist - or a Short History of Identity, in Questions of Cultural Identity, eds. S. HALL and P. du GAY, London.

BERDJAJEV, Nikolaj

1937: Ljudska licnost i marksizam, u Komunizam i krscani, Zagreb, 164-187.

CVIJIC, Jovan

1987: Balkansko poluostrvo, Beograd.

CAJKANOVIC, Veselin

1985: O magiji i religiji, Beograd.

${ }^{24}$ We asked interviewees to name the term which best describes the Serbian nation: less than $15 \%$ of them would present the nation with some of the terms in connection with Orthodox Christianity. 
DJORDJEVIC, B. Dragoljub

1987: Studenti i religija, Nis.

FROMM Erich

1986: Zdravo drustvo, Zagreb.

GolubOVIC, Z.-KuZMANOVIC, B.-VASOVIC, M

1995: Drustveni karakter i drustvene promene u svetlu nacionalnih sukoba, Beograd.

JEROTIC, Vladeta

1997: Hriscantvo i psiholoski problemi coveka, Beograd.

JOVANOVIC, Slobodan

1992: Srpski nacionalni karakter, O kulturnom obrascu”, u Karakterologija Srba, urednik B. JOVANOVIC, Beograd, 229-242.

JUNG, Karl Gustav

1977: Psiholoske rasprave, Novi Sad.

1984: Psihologija i alhemija, Zagreb.

KUZMANOVIC, Bora

1997: Setnjom u slobodu - Vrednosne orijentacije i politicki stavovi ucesnika Protesta 96/97, u Grupa autora, Ajmo, ajde, svi u setnju, Gradjanski i studentski protest 96/97, Beograd 51-64.

1990: The New Testament, authorized (King James) Version, Zagreb.

PAVICEVIC, Vuko

1980: Sociologija religije sa elementima filozofije religije, Beograd.

RisTOVIC, Milan

1995: Socijalna struktura Jugoslavije - jedna analiza britanskog Foreign Office Research Department-a sa kraja 1944. godine, u Godisnjak za drustvenu istoriju, god. II sveska 1, Beograd.

VRATUSA-ZUNJIC, Vera

1997: Odnos verske pripadnosti, religiozne samoidentifikacije i medjuetnicke distance u bivsoj Jugoslaviji krajem osamdesetih, rezime priloga za IV godisnju konferenciju JUNIR-a, Niska Banja. VRCAN, Srdjan

1981: Studenti i religija: izmedju cvrste povezanosti za religiju i masovnog otudjivanja od religije (vezanost studenata Sveucilista u Splitu za religiju), u Sociologija 1-2, Beograd. 